IRA-International Journal of Management \& Social Sciences

ISSN 2455-2267; Vol.07, Issue 01 (2017)

Pg. no. 39-44

Institute of Research Advances

https://research-advances.org/index.php/RAJMSS

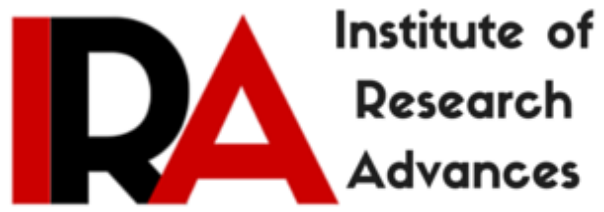

\title{
The Changing Role of Marketing in the Third Millennium
}

\section{Ms. Reshma Sreedharan}

Assistant Professor, School of Management Studies,

Chinmaya Institute of Technology, Govindagiri, Chala, Kannur - 670007, India.

\section{Dr. Rehin K R}

Assistant Professor, School of Management Studies,

Chinmaya Institute of Technology, Govindagiri, Chala, Kannur - 670007, India.

Type of Review: Peer Reviewed.

DOI: http://dx.doi.org/10.21013/jmss.v7.n1.p5

\section{How to cite this paper:}

Sreedharan, R., \& KR, R. (2017). The Changing Role of Marketing in the Third

Millennium. IRA-International Journal of Management \& Social Sciences (ISSN 2455-2267), 7(1), 39-44. doi:http://dx.doi.org/10.21013/jmss.v7.n1.p5

(C) Institute of Research Advances

\section{(cc) EY-NC}

This work is licensed under a Creative Commons Attribution-Non Commercial 4.0 International License subject to proper citation to the publication source of the work.

Disclaimer: The scholarly papers as reviewed and published by the Institute of Research Advances (IRA) are the views and opinions of their respective authors and are not the views or opinions of the IRA. The IRA disclaims of any harm or loss caused due to the published content to any party. 
In the $21^{\text {st }}$ century, any marketer has to face stiff competition due to the dynamic environment. Nowadays, marketers are offering more value to the customers so that they can gain a competitive advantage. The present customers are now digitally conscious and are opposing the traditional way of marketing. The marketers have to identify the new techniques which can be used to target the new millennium customers and earn sizeable profits. This paper focuses on the emerging marketing trends and its repercussions.

Keywords: Behavioural marketing, direct and online marketing, live-streaming, relationship marketing, societal marketing, viral marketing

\section{Introduction}

Marketing is one of the essential elements for any business to be successful. The prime motive of any business activity is to attract, satisfy, and retain customers. The companies are formulating strategies to create customers. They use the 4P's of marketing mix to summarize the important elements in marketing strategy. A full-fledged marketing plan is prepared to find out how the company is going to implement the strategy to meet their objectives. Every year the company fixes a marketing budget but it should be kept flexible due to the environmental changes. Also, the companies spend enough money on advertising which can be futile. Just spending money is not enough; the companies have to monitor their customers and competitors. They need to understand the strategic move of their competitors. Also, they need to understand the customer expectations. They have to continuously improve their value offerings and incorporate changes at frequent time intervals. It will never be an exaggeration to mention that marketing is the most complex, industrious, and challenging function in any business.

Due to Liberalization, Privatization and Globalization, the whole world has become a single market. The companies can now expand its market beyond their borders. In order to be globally competitive, it is significant to create and innovate new and better products and services. Companies cannot continue with their old traditions, customs, and assumptions about their customers. But they have to adapt as per the different cultural requirements. It's the time to "Act locally but think globally". Being an information age, companies have to combine computers, telecommunications and information technology to create value to their customers. The Information Technology revolution has created a new direction to the marketing practices. The marketer has to use technology which can help them connect the customers $24 \times 7$. Marketing concept has now changed from just pushing the products to being connected with customers. Considering the shift in the role of marketing in the third millennium, it becomes relevant to understand the emerging trends.

\section{Review of Literature}

Kumar \& Shah (2004) stated that internet has brought a shift in the consumer behaviour. So, the marketers have to give more information through web to pull the customer instead of the traditional style where the marketers deploy push strategy to arouse customer interest. Internet can create closer but cost-effective relationships with the customer and it will help in maintaining a long term relationship also. Geld (2003) mentioned that Internet marketing can target the different audience by have several electronic versions of the same catalogue at less cost. It is highlighted that money is the major point which differentiates traditional marketing from internet marketing. Arora (2004) stated that almost $60 \%$ of the revenue is earned by five firms - Google, Yahoo, Microsoft, America Online Launchers, and Overture. Weerawardena (2006) describes that any marketing firm is concerned with having a prominence in the industry, for which it will constantly analyse the market trends and then plan it's performance. The main drivers of earning profits through customers are technological advancements and innovations, competitive marketing environment along with the internet (Chou et al, 2003). Today many firms have understood that to sustain a competitive edge they have to implement CRM (Peppard, 2000). Kotler (2000) stressed that the business standards will be enhanced by satisfying the stakeholders. These satisfied stakeholders will enhance the corporate reputation as a firm which maintains the consumer's and society's well-being. In the current $21^{\text {st }}$ century, the firms are contributing towards solving the societal issues through marketing for safeguarding the interests of 
key stakeholders (Marsden 2000; McAlister \& Ferrell 2002). Pringle and Marjorie has termed societal marketing as cause-related marketing as it builds partnership for mutual benefit. The attitude and behaviour of the customers can be easily influenced through supporting the charity events (Barone, Miyazaki \& Taylor 2000; Bennett \& Gabriel 2000; Ellen, Mohr \& Webb 2000). Through societal marketing the corporate should strike a by fulfilling the needs of the consumers, society and objectives of the organization (Kotler 2000; Bednall \& Kanuk 1997). By implementing societal marketing, the corporate can gain a competitive advantage (Kotler 2000; Porter \& Kramer 2002).

\section{Emerging Trends in Marketing in the Third Millennium}

The developments in Information Technology and Telecommunications have made a drastic change in marketing in the third millennium. Consumers in the $21^{\text {st }}$ century are very different from the earlier decades as they are not loyal to a particular brand and also not sensible to advertising. Few of the emerging trends in the third millennium are listed below:

\section{Relationship Marketing}

It is a facet of customer relationship management (CRM) which focuses on developing and managing long-term relationship with the customers with the help of extended communication which is beyond intensive promotional messages. It has a broader aspect like customer retention and satisfaction rather than just customer acquisition and making sales. The common belief of marketers is that "customer retention is easier than customer creation. Berry (1983) stated that "Relationship marketing is attracting, maintaining and in multi service organisations - enhancing customer relationships". While, Barbara (1985) referred it as marketing oriented towards strong, lasting relationships with individual accounts. It is necessary to have continuity in relationship, trust and communication to have a long term relationship with the customers. The positive implication of relationship marketing is that there is a social contact with each customer which creates trust and increases the commitment from the customer towards the company. It can lead to partnering which can improve the long term financial performance of the company. Relationship marketing can reduce the cost of acquisition due to the referrals by the satisfied customers. As the customers are retained, it makes difficult for new entry to the market. The negative implication of relationship marketing is that it involves cost and giving value to the existing customer does not guarantee that they will buy repetitively from the company. A single negative experience of the existing customer can get shared with the other customers and finally may result in vulnerable failure. Having close relationship with the existing customers can sometimes create trouble for the company. It can create a step-motherly feeling to the new customers. The pros and cons of relationship marketing if planned properly and made flexible can add reputation to the brand. Kanagal (2009) concluded that "Relationship Marketing is a tool for furthering the customer understanding and interactive processes".

\section{Societal Marketing}

It is a strategic decision taken by the organization to determine the needs of the customer, the requirements of the organization, and the long-term interest of the society. It delivers optimum satisfaction to the customer but by maintaining an ecological balance. There is a high correlation of societal marketing, corporate social responsibility and sustainable development. Through societal marketing, the companies should deliver value which ensures both customer and societal welfare. This concept holds that the customers should be satisfied efficiently and effectively than competitors. Consumers expect from companies to act upon environmental issues rather than just concentrating on profit. This portrays a sign of good corporate citizenship behaviour. It can build the image of the company and the company can gain a competitive edge over their competitors. It increases customer loyalty and build sales. To implement societal marketing a balance between the needs of stakeholders and environment has to be met. The downside of this approach is that customers may feel that they are fulfilling the philanthropic activity by using the product so no need to contribute directly. The customers may feel that they are satisfied at the society's expense. The companies have to always balance among the company profits, customer satisfaction and public interesting which are of conflicting nature. Through societal marketing concept, a proactive effort is made by the company to give back something in return to the society. 


\section{Direct and Online Marketing}

It is an advertising technique which communicates directly to the targeted individual customers to get an immediate response. Today most of the direct marketers give information about their products, special events, and prizes through cell phone text messaging, websites, email, online adverts and catalogues. This technique has reduced the dependency on the wholesale and retail intermediaries. The advancement in the IT and communication has changed the way of buying and selling. Online marketing is done through interactive online computer systems which link consumers with sellers electronically. With the help of internet, people anywhere in the world can check for the offers and place order by comparing among the thousands of product and services displayed on the website. Also, the company does the buying through Electronic data interchange link. Overall, it enhances the efficiency of buying and selling. Both, Direct and Online marketing are the tools for building customer relationship. It can bring the company and customer closer to each other. It is less costly, efficient and can reach the buyers at a faster speed. It gives greater scope for flexibility as the marketer can make adjustments in their offers and schemes. The flip side of direct and online marketing is that there can be public cynicism towards the messages sent by the company. Customers may feel annoyed about the uninvited marketing and promotional content. The marketer will have to incur higher initial costs for using this tool of advertising.

\section{Behavioural Marketing}

Consumer behaviour is a decision making process that influences the buying and using of the goods and services (Engel, 1985). It is a marketing technique which uses the online information and customizes the message to each user. It profiles the behaviour of the online users and tries to understand the needs, habits and desires of the user with the usage of web analytics, computer applications and cookies, browsing and searching history, and IP addresses. The advertisements are designed according to the interests of the customer. Geng (2006) stated that Behavioural targeting assesses each user and uses different advertisements leading to selling of individual products. It creates a greater impact as the ad focuses on the individual customers. It makes an appeal and helps in reaching to the receptive audience who can be easily converted to prospects or customers whereby earning profits through digital advertisements. Many customers are concerned about the privacy issues. It can be resolved through education, support, and getting prior permission from the online users. As the number of online users is increasing rapidly, behavioural marketing can help in increasing sales with less wastage of resources. Rozic (2001) mentioned that advertisers are more prepared to put ads online as there is much probability of it getting clicked on. According to Chen (2014) in an article on analyzing the online advertised concluded that small advertisers are generally better off under behavioural targeting by winning their targeted users than the dominant advertiser.

\section{Viral Marketing}

It is a technique that persuades a website or an user to forward a marketing message to other user or sites. It spreads the information about a product or service through the social networking sites. It is similar to word of mouth marketing but with the help of internet-based platforms, it can be called word of mouse. When another person tells your story, it can have a quick action. The message spread through viral marketing can create more visibility and effect. Jurvetson (2000) articulated that "Viral marketing is more powerful than an agency advertising the product or service as it is an third-party advertising because it is an endorsement by a friend which is implicit". Even if the product does not have any new element, the people who spreads the message needs to be self interested. This technique is likely to reach more effectively to the audience than the traditional advertising. Compared to other forms of advertising and marketing campaigns, viral marketing is comparatively inexpensive (Dobele, et al., 2005, Kaikati \& Kaikati, 2004, Welker, 2002). The online users will embrace the viral campaign even if they like it or not. It reaches the audience in a short time period (Kaikati \& Kaikati, 2004) as messages spread at a faster speed (Helm, 2000, Welkar, 2002). So, the products marketed through viral marketing will be easily accepted by the audience (Dobele, et al., 2005). Like other marketing techniques, it can be a hit or a miss. If viral marketing is executed properly, then it can increase the marketers ROI. If it is not done properly then it would jeopardize the marketer's position. The greatest problem with viral campaign is the lack of control, as organisations have does not have the power to 
control the message which is spreaded and also on the content which gets transmitted (Dobele, et al., 2005, Helm, 2000, Kaikati \& Kaikati, 2004, Welker, 2002). The consumer may ask for some favour in return for spreading the message. There is a lack of ethical standards (Kaikati \& Kaikati, 2004). Also, the customers may feel exploited, cheated, and used (Dobele, et al., 2005). But certainly by proper strategies and social contacts, the marketer can earn huge profits.

\section{Live Streaming}

It is a tool which delivers the content in real-time to the customers. The customers can interact and ask questions with the company officials about the content which is shared through internet. It can be used for sharing some important announcements about the company, new product, industry related news, and brand ambassador. It removes the hassle of scheduling a press conference or facilitating a formal webinar. It is much cheaper than using commercial television transmission as with the help of internet it can cover the whole world. The information can be shared easily and an intimacy can be created with the audiences. It can help in engaging the customer with the company for a longer term. A strong branding message can be created through live streaming but it should be ensured that everyone hears the same message. New live streaming platforms, better content, faster connection speeds, and bigger data plans, will make it easier for many companies to adopt this tool for future marketing.

\section{Conclusion}

Marketing function is inevitable and has to be done in all types of firms. With the advent of Information Technology, the role of marketing has changed. The expectations of the new millennium customers are exorbitant as they are able to get any information at their fingertips. The traditional style of marketing will not help companies to withstand competition. It has to seek the new techniques and tools of marketing. Companies have to get out of their comfort zone and implement the emerging trends for marketing their products and services. For making itself profitable, it has to consider the flip side of each technique and select the tools properly. Hence, it can be concluded that there are changes happening in the last few years but with a long term consequences.

\section{References}

- Barbara, J. (1985). Winning and keeping industrial customers. Lexington, MA'Lexington Books.

- Barone, M. J., Miyazaki, A. D., \& Taylor, K. A. (2000). The influence of cause-related marketing on consumer choice: does one good turn deserve another?. Journal of the academy of marketing Science, 28(2), 248-262.

- Bauer, C. L., \& Miglautsch, J. (1992). A conceptual definition of direct marketing. Journal of Direct Marketing, 6(2), 7-17.

- Bednall, S., \& Kanuk, W. (1997). Consumer behaviour. Prentice Hall, Sydney.

- Bennett, R., \& Gabriel, H. (2000). Charity affiliation as a determinant of product purchase decisions. Journal of Product \& Brand Management, 9(4), 255-270.

- Berry, L. (1983). Relationship Marketing in Emerging Perspectives on Services Marketing/Berry Leonard.

- Brosekhan, A. A., Velayutham, C. M., \& Phil, M. (2013). Consumer buying behaviour-a literature review. IOSR Journal of Business and Management, 9.

- Canavan, O., Henchion, M., \& O'Reilly, S. (2007). The use of the internet as a marketing channel for Irish speciality food. International Journal of Retail \& Distribution Management, 35(2), 178-195.

- Chen, J., \& Stallaert, J. (2014). An economic analysis of online advertising using behavioral targeting. Mis Quarterly, 38(2), 429-449.

- Dobele, A., Toleman, D., \& Beverland, M. (2005). Controlled infection! Spreading the brand message through viral marketing. Business Horizons, 48(2), 143-149.

- Ellen, P. S., Mohr, L. A., \& Webb, D. J. (2000). Charitable programs and the retailer: do they mix?. Journal of retailing, 76(3), 393-406.

- Geng, X., Stinchcombe, M. B., Whinston, A. B., \& Hendershott, T. (2006). Product 
bundling. Handbook of Economics and Information Systems, 499-525.

- Helm, S. (2000). Viral marketing-establishing customer relationships by'word-ofmouse'. Electronic markets, 10(3), 158-161.

- Jurvetson, S. (2000). What exactly is viral marketing. Red Herring, 78, 110-112.

- Kaikati, A. M., \& Kaikati, J. G. (2004). Stealth marketing: how to reach consumers surreptitiously. California Management Review, 46(4), 6-22.

- Kanagal, N. (2009). Role of relationship marketing in competitive marketing strategy. Journal of Management and Marketing Research, 2, 1.

- Kotler, P. (2007). Marketing Management-The Millennium Edition Prentice Hall of India Private Limited. New Delhi, 35-38.

- Kotler, P., \& Armstrong, G. (2010). Principles of marketing. pearson education.

- Kumar, V., \& Shah, D. (2004). Pushing and Pulling on the Internet. Marketing Research, 16(1), 28-33.

- Leskovec, J., Adamic, L. A., \& Huberman, B. A. (2007). The dynamics of viral marketing. ACM Transactions on the Web (TWEB), l(1), 5 .

- Marsden, C. (2000). The new corporate citizenship of big business: Part of the solution to sustainability?. Business and Society Review, 105(1), 8-25.

- Peppard, J. (2000). Customer relationship management (CRM) in financial services. European Management Journal, 18(3), 312-327.

- Porter, M. E., \& Kramer, M. R. (2002). The competitive advantage of corporate philanthropy. Harvard business review, 80(12), 56-68.

- Pringle, H., \& Thompson, M. (1999). Brand spirit. Great Britain: John Wiley \& Sons.

- Rozic, J. (2001). Who's Watching While You Surf?. Inside Business, 3(5), 64.

- Thorne McAlister, D., \& Ferrell, L. (2002). The role of strategic philanthropy in marketing strategy. European Journal of Marketing, 36(5/6), 689-705.

- Vidaver-Cohen, D., \& Altman, B. W. (2000). Corporate citizenship in the new millennium: Foundation for an architecture of excellence. Business and Society Review, 105(1), 145-168.

- Weerawardena, J. \& Sullivan Mort, G (2006). Investigating social entrepreneurship: A multidimensional model. Journal of World Business, 41, pp. 21-35.

- Welker, C. B. (2002). The paradigm of viral communication. Information Services \& Use, 22(1), 3-8.

- Woerndl, M., Papagiannidis, S., Bourlakis, M., \& Li, F. (2008). Internet-induced marketing techniques: Critical factors in viral marketing campaigns.

- Xu, Y., Yen, D. C., Lin, B., \& Chou, D. C. (2002). Adopting customer relationship management technology. Industrial management \& data systems, 102(8), 442-452. 